\title{
PARTYCYPACJA OBYWATELI W POLITYCE ROZWOJU ŚLĄSKICH MIAST
}

\author{
CITIZEN PARTICIPATION IN THE POLICY-MAKING \\ OF SILESIAN CITIES
}

DOI: $10.25167 / \mathrm{sm} 2017.025 .07 \quad$ s. $121-131$

\begin{abstract}
ABSTRAKT: Zagadnienie partycypacji mieszkańców nabiera na znaczeniu w praktyce działania polskich miast. Należy jednak zauważyć, że podejmowane inicjatywy w tym zakresie mogą mieć charakter fakultatywny bądź wynikający z regulacji ogólnokrajowych. Doświadczenia poszczególnych ośrodków miejskich w kierunku angażowania mieszkańców i uspołecznienia procesu rozwoju lokalnego są zatem bardzo zróżnicowane. W celu propagowania dobrych praktyk niezbędne jest usystematyzowanie wiedzy w przedmiotowym obszarze badań oraz diagnoza dokumentów strategicznych poszczególnych samorządów i realizowanych inicjatyw w praktyce. Artykuł ma na celu przynajmniej częściowe wypełnienie luki w przedstawionym obszarze badawczym, zawężając perspektywę badawczą do granic administracyjnych województwa śląskiego. Zaprezentowano w nim znaczenie partycypacji obywatelskiej w polityce lokalnej, odwołując się do praktyk wybranych śląskich miast: Rybnika, Częstochowy oraz Dąbrowy Górniczej.
\end{abstract}

SŁOWA KLUCZOWE: samorząd gminny, społeczeństwo obywatelskie, narzędzia partycypacji, zrównoważony rozwój

ABSTRACT: The issue of inhabitants' participation in policy making is becoming more and more important in the practice of Polish cities. It should be noted, however, that the undertaken initiatives can be both optional or resulting from the national regulations. Therefore the experience of different cities in terms of citizen involvement and empowerment of the process of local development are very diverse. In order to promote good practices we need to systematize knowledge relating to the topic in question. We also need to analyze strategic documents elaborated by cities and initiatives realized in practice. The article aims - at least partially - to fill in the gap existing in the presented scientific field, based on examples from the region of Silesia. It focuses on civic participation in the local policy in selected Silesian cities: Rybnik, Częstochowa and Dąbrowa Górnicza.

KEY WORDS: municipal government, civic society, participatory tools, sustainable development

* Uniwersytet Ekonomiczny w Katowicach, Katedra Gospodarki Przestrzennej i Środowiskowej, ul. 1 Maja 50, 40-287 Katowice, e-mail: agnieszka.sobol@ue.katowice.pl

** Uniwersytet Ekonomiczny w Katowicach, Katedra Ekonomii Politycznej, ul. 1 Maja 50, 40-287 Katowice, e-mail: monika.drzewiecka@ue.katowice.pl 


\section{Wprowadzenie}

Partycypacja obywateli w polityce samorządowej w Polsce staje się coraz bardziej powszechna. Władze lokalne mają do dyspozycji szerokie spektrum narzędzi wsparcia inicjatyw oddolnych oraz instrumentów umożliwiających angażowanie mieszkańców w rozwój lokalny. Polityka w kierunku uspołecznienia ma bowiem charakter dwutorowy, tj. z jednej strony realizowane są zadania inicjowane przez władze lokalne, z drugiej strony działania podejmowane są przez samych mieszkańców. Ponadto część stosowanych rozwiązań w zakresie partycypacji obywatelskiej jest przedmiotem regulacji ogólnokrajowych, a część jest wynikiem dobrowolnych, powstających lokalnie pomysłów. Nie ma zatem ujednoliconego katalogu instrumentarium udziału mieszkańców w procesie rozwoju lokalnego. Przyjęcie takiego rozwiązania jest zasadniczo zbieżne z zasadą samorządności i dopasowywania rozwiązań do określonych specyficznych warunków lokalnych. Zauważalne są jednak duże dysproporcje w poziomie zaawansowania gmin w Polsce w zakresie uspołecznienia rozwoju lokalnego.

Część gmin stosuje biurokratyczną linię, ograniczając się jedynie do przepisów odgórnych wynikających z legislacji krajowej. Zauważyć ponadto należy, iż pomimo częściowo narzuconych przez przepisy prawa rozwiązań w zakresie udziału mieszkańców w rozwoju lokalnym gminy nie stosują ich w pełnym zakresie. Nie są w związku z tym praktykowane wobec gmin sankcje.

Realizacja polityki uspołecznienia jest ściśle związana ze świadomością władz lokalnych roli obywateli w życiu publicznym. Rozumienie przez władze istoty uspołecznienia stanowi bowiem fundament uczciwych i rzeczywistych (a nie pozorowanych) praktyk w tym zakresie. W sytuacji, gdy uruchomienie mechanizmów partycypacji mieszkańców jest raczej wynikiem taktyki politycznej poprawności, podbudowa całego procesu jest niestabilna. Wprowadzane mechanizmy, np. konsultacje społeczne, są wówczas jedynie celem legitymizacji decyzji władz. Partycypacja, która wynika z kalkulacji politycznej, charakteryzuje się także większą liczbą błędów organizacyjnych. Ponadto mieszkańcy często wyczuwają nieszczerość podejmowanych działań. W rezultacie ich zaangażowanie jest słabe, co daje władzom pretekst, by z części rozwiązań się wycofać lub je ograniczyć.

Celem artykułu jest prezentacja, jak założenia strategiczne dotyczące partycypacji mieszkańców, przyjmowane na różnych szczeblach administracji publicznej, mogą kształtować politykę rozwoju miasta. W związku z tym sformułowano następujące pytania badawcze: Czy zachodzi spójność założeń w zakresie partycypacji obywatelskiej w dokumentach strategicznych opracowywanych na różnych poziomach administracji samorządowej? Jak obligatoryjne regulacje w połączeniu z rozwiązaniami fakultatywnymi mogą sprzyjać partycypacji mieszkańców w rozwoju miasta?

Struktura artykułu wynika z przyjętego celu i kolejno zostaną przedstawione: istota partycypacji obywatelskiej i jej uwarunkowania w procesie rozwoju lokalnego w Polsce, odniesienia do partycypacji mieszkańców w dokumentach strategicznych oraz przykłady dobrych praktyk realizowanych w samorządach w województwie śląskim. 


\section{Istota partycypacji obywatelskiej}

Wzrost znaczenia roli mieszkańców w życiu publicznym jest efektem wielu bezpośrednich i pośrednich procesów związanych z demokratyzacją i decentralizacją władzy. Partycypacja mieszkańców w życiu społecznym, zwłaszcza lokalnym, przejawia się w aktywnym uczestnictwie w życiu danej wspólnoty, angażowaniu się w inicjatywy i wydarzenia organizowane przez innych współmieszkańców i instytucje oraz samodzielne podejmowanie inicjatyw oddolnych. Upodmiotowienie mieszkańców w drodze wprowadzania mechanizmów partycypacyjnych umożliwia optymalizację oferty miejskiej pod względem jej użyteczności i dostępności dla mieszkańców (Foster-Fishman et al. 2009). Rezultaty uspołecznienia zależne są od wszystkich podmiotów uczestniczących w tym procesie. Wymagają bowiem współdziałania różnych aktorów lokalnych, a ich zaangażowanie i wzajemne relacje determinują cały proces (Kooiman, Van Vliet 1993, s. 64). Ważną kategorią jest tu zaufanie, którego znaczenie akcentowane przez wielu badaczy, z Francisem Fukuyamą na czele, ma niezależny pozytywny wpływ na aktywność obywatelską (Fukuyama 1997). Na niezbędność zaufania dla kształtowania aktywnych wspólnot lokalnych wskazywali także wcześniej Manuel Castells oraz Robert Putnam (Castells 1983, Putnam 1995).

Partycypacja ma charakter stopniowalny - od informowania mieszkańców aż do współrządzenia (Biała księga... 2014). Analizy wpływu mieszkańców na rozwój lokalny opierają się często na koncepcji drabiny społecznej partycypacji autorstwa Sherry R. Arnstein. Obejmuje ona osiem szczebli, z których dwa pierwsze - manipulacja i terapia - uniemożliwiają partycypację obywatelską. Kolejne, tj. informowanie i konsultacje, odnoszą się do sytuacji, kiedy mieszkańcy są informowani i mogą być wysłuchani. Kolejne dwa szczeble - łagodzenie i partnerstwo - umożliwiają doradzanie przez mieszkańców, ale decyzje pozostają w rękach rządzących. Na szczycie drabiny znajduje się delegowanie władzy, m.in. poprzez negocjacje i współdziałanie, oraz pełna kontrola obywatelska (Arnstein 1969).

W literaturze wskazuje się na wielorakie korzyści wynikające ze współuczestnictwa mieszkańców w procesie rozwoju lokalnego (Michels, De Graff 2010):

1. pomaga w edukacji obywatelskiej (funkcja edukacyjna);

2. zwiększa rzeczywistą kontrolę obywateli nad władzą (funkcja legitymizacji decyzji);

3. pomaga w tworzeniu identyfikacji społeczności lokalnej (funkcja integracyjna);

4. stwarza dodatkowe okazje do wymiany argumentów (funkcja deliberacyjna).

Partycypacja społeczności lokalnej pozwala na rzeczywiste rozpoznanie i uwzględnianie potrzeb i oczekiwań mieszkańców w kształtowaniu ich najbliższego otoczenia. Ma zatem wpływ na optymalizację oferty miejskiej i poprawę jakości życia. Należy jednak zauważyć, iż złe doświadczenia z partycypacji osłabiają chęć jej kontynuowania zarówno przez mieszkańców, jak i władze lokalne (Wouters, Hardie-Boys, Wilson 2011). Ponadto uspołecznienie rozwoju jest procesem długotrwałym i wymagającym dużego zaangażowania wszystkich partnerów w mieście. 


\section{Uwarunkowania partycypacji obywatelskiej w Polsce}

Partycypacja w rządzeniu na poziomie wspólnot terytorialnych przybiera różne formy, a także jest w różnym stopniu zinstytucjonalizowana. Można przyjąć, że partycypacja społeczna w polskich gminach zależy w głównej mierze od: postawy obywateli, działania władz samorządowych oraz prawa państwowego (Borek, Fenrych, Margol 2010). Do czynników sprzyjających wysokiemu poziomowi partycypacji publicznej zalicza się: korzystanie z funduszy unijnych, dynamikę lokalnej sceny politycznej, szczególne akty prawne, siłę mediów lokalnych i organizacji pozarządowych, aktywizacyjną i identyfikacyjną funkcję konfliktów między władzą a mieszkańcami (Olech 2013).

Uwarunkowania partycypacji obywatelskiej w Polsce mają silny kontekst historyczny. Bagaż doświadczeń Polaków ciąży na ich aktywności i zaangażowaniu w życie publiczne. Potwierdzają to także czynniki, które Anna Olech uznała za niesprzyjające partycypacji mieszkańców w podejmowaniu decyzji dotyczących wspólnot lokalnych (Olech 2013):

- brak kompetencji mieszkańców oraz ich niska aktywność publiczna;

- traktowanie demokracji przedstawicielskiej jako optymalnej formuły zarządzania gminą;

- niski poziom kapitału i potencjału społecznego;

- konflikty między mieszkańcami;

- funkcjonalne właściwości gminy wyrażające się m.in. w poczuciu mieszkańców bycia członkami danej społeczności lokalnej.

Autorzy raportu o stanie samorządności w Polsce podkreślają, że obecny porządek instytucjonalny nie sprzyja aktywności obywatelskiej i obecności obywateli w przestrzeni publicznej. Obywatele są zasadniczo z niej wypierani i wycofują się do sfery prywatnej. A jeśli już pojawiają się w przestrzeni publicznej, to jako klienci podmiotów władzy, reprezentanci indywidualnych lub korporacyjno-zawodowych interesów (Hausner et al. 2014).

Największe badania dotyczące stanu społeczeństwa obywatelskiego w Polsce realizowane są od 2000 r. w kolejnych edycjach „Diagnozy społecznej” (Diagnoza... 2015). Okresowo publikowane są także raporty Stowarzyszenia Klon/Jawor na temat działalności organizacji pozarządowych w Polsce oraz aktywności społecznej Polaków (Kondycja... 2016). Prezentowane badania postaw obywatelskich wskazują jednoznacznie na stan słabego zaangażowania Polaków w życie publiczne.

Zgodnie z danymi prezentowanymi w raporcie „Diagnoza społeczna 2015” członkami różnego rodzaju organizacji społecznych jest 13,4\% mieszkańców, w tym aktywnych jest ok. 9\% członków. Obserwowany w ciągu ostatniej dekady powolny, ale systematyczny wzrost zaangażowania Polaków w działania na rzecz lokalnej społeczności zatrzymał się na poziomie 15\%. Generalnie Polacy prezentują małe doświadczenia i kompetencje obywatelskie (Diagnoza... 2015, s. 22).

Paweł Swianiewicz wskazuje na istotną rolę rozwiązań legislacyjnych, wspierających lub nawet wymuszających większą intensywność interakcji między władzami 
samorządowymi a społecznością lokalną. Dobre prawo umożliwia, a czasem pobudza innowacyjne rozwiązania w tym zakresie (Swianiewicz 2012). Jednak wprowadzane narzędzia wpływania przez mieszkańców na samorząd pozostają często niewykorzystane. Przykładem może być inicjatywa uchwałodawcza mieszkańców, która w wielu samorządach jest pustym zapisem (Borek, Fenrych, Margol 2010).

Ważnym momentem budowania tożsamości z samorządem lokalnym było wprowadzenie w 2002 r. bezpośrednich wyborów na urzędy wójtów, burmistrzów i prezydentów miast ${ }^{1}$. Umożliwienie mieszkańcom bezpośredniego wyboru gospodarza spraw lokalnych wpływa na ich większą identyfikację i zaangażowanie w rozwój lokalny. Znaczenie partycypacji obywatelskiej w życiu publicznym wzmocnione zostało ponadto poprzez uchwaloną w 2003 r. ustawę o działalności pożytku publicznego i o wolontariacie. Dzięki niej organizacje pożytku publicznego uzyskały prawne gwarancje stania się partnerem we współpracy z jednostkami samorządu terytorialnego. Partnerstwo organizacji pożytku publicznego oraz organów administracji samorządowej wyraża się w szczególności w kilku działaniach, do których należą:

- powoływanie Gminnych Rad Działalności Pożytku Publicznego (art. 41e);

- uchwalanie przez samorząd terytorialny rocznego programu współpracy z organizacjami pozarządowymi (non governmental organisations - NGO), z obowiązkiem jego przyjęcia do 30 listopada każdego roku, oraz składania sprawozdań do 30 kwietnia z wykonania programu współpracy z organizacjami za rok poprzedni (art. 5a);

- określenie sposobu i procedury konsultowania aktów prawa miejscowego w dziedzinach dotyczących działalności statutowej NGO (art. 41i);

- określenie sposobu i procedury konsultowania przez NGO strategii rozwoju gminy (art. 41i);

- określenie trybu i kryteriów inicjatywy lokalnej jako prawa do realizowania zadań publicznych przez samych mieszkańców (art. 19b, 19c).

Istnieje także możliwość dofinansowania aktywności obywatelskiej z budżetu samorządu. Jednak system wsparcia finansowego może budować organizacje o charakterze „klienckim” wobec władz samorządowych bądź opozycyjnych z powodu nieotrzymania dotacji (Borek, Fenrych, Margol 2010).

Ustawa o działalności pożytku publicznego i wolontariacie wzmocniła NGO w procesie rozwoju lokalnego. Niestety wciąż zbyt słabe i mało czytelne są pozycja i możliwości udziału przeciętnego mieszkańca. Trudności w zakresie możliwości zaangażowania się obywatela niezrzeszonego w żadnej organizacji były m.in. przesłanką projektu ustawy o współdziałaniu w samorządzie terytorialnym na rzecz rozwoju lokalnego i regionalnego oraz o zmianie niektórych ustaw przygotowanego przez Kancelarię Prezydenta Bronisława Komorowskiego. Przyszłość regulacji w nim zaproponowanych jest jednak nieznana. Dotychczasowe regulacje przewidują dla mieszkańców dość

\footnotetext{
1 Ustawa ta została uchylona w 2011 r. w drodze uchwalenia Ustawy z 5 stycznia 2011 r. - Kodeks wyborczy (Dz.U. z 2011 r. Nr 21, poz. 112 z poźn. zm.).
} 
ograniczony zakres partycypacji w procesie rozwoju lokalnego. Podstawowy przepis, tj. art. 5a ustawy o samorządzie gminnym, wskazuje, iż w wypadkach przewidzianych ustawą oraz w innych sprawach ważnych dla gminy mogą być przeprowadzane na jej terytorium konsultacje z mieszkańcami gminy. Niestety konsultacje społeczne w rzeczywistości gminnej nie są zbyt powszechne. Jednocześnie te, które są organizowane, często nie są dostatecznie nagłaśniane i w rezultacie przechodzą bez echa. Inicjatywa lokalna jest także mało znanym i trudnym organizacyjnie rozwiązaniem.

Wydaje się, że w praktyce samorządów gminnych najbardziej czytelną i najlepiej promowaną formą uspołecznienia rozwoju lokalnego są budżety obywatelskie (BO) zwane także budżetami partycypacyjnymi. BO opierają się na generalnej konstrukcji wyprowadzonej z art. 5a ustawy o samorządzie gminnym. Na podstawie tej klauzuli rady poszczególnych gmin w drodze uchwały mogą zdecydować o wprowadzeniu BO i przekazaniu części budżetu gminy do decyzji mieszkańców. Jest to zatem narządzie w obecnym jego kształcie całkowicie fakultatywne, zarówno w sensie faktu wprowadzenia, jak i w sensie proceduralnym.

Przełamanie niskiego zaangażowania mieszkańców w rozwój gminy wiąże się z koniecznością tworzenia różnorodnych kanałów komunikacji. Dialog oraz charakter informacji wpływają na kształtowanie się postaw i zachowań obywatelskich oraz wpływają na podejmowane przez władze decyzje (Krakowiak-Drzewiecka 2015). Ponadto angażowanie mieszkańców w przestrzeni lokalnej powinno mieć z zasady bardziej aktywny i bezpośredni charakter. Sprzyja temu stosowanie nowoczesnych narzędzi teleinformacyjnych, dzięki którym pozycja przeciętnego obywatela radykalnie wzrosła. Możliwości zaangażowania się w życie publiczne bez wychodzenia z domu i na zasadach anonimowości stanowią współcześnie istotną zmianę jakościową budowy społeczeństwa obywatelskiego (Sobol 2014).

\section{Partycypacja obywatelska w regionalnych dokumentach strategicznych}

Wyznaczając cele polityki rozwoju, władze samorządowe powinny brać pod uwagę nie tylko obowiązujące uwarunkowania prawne, ale również założenia zawarte w europejskich, krajowych oraz regionalnych dokumentach strategicznych. Celem analizy $\mathrm{w}$ artykule jest pokazanie powiązania założeń strategicznych w zakresie partycypacji różnych szczebli samorządu województwa śląskiego.

W Strategii Rozwoju Województwa Śląskiego „Śląskie 2020+” wielokrotnie pojawiają się odniesienia do konieczności rozwoju społeczeństwa obywatelskiego, a tym samym wspierania rozwiązań gwarantujących większe zaangażowanie mieszkańców regionu w podejmowanie decyzji dotyczących ich wspólnot lokalnych. Podstawowe wyzwania polityki rozwoju województwa obejmują m.in.: „Wzrost uczestnictwa społeczności lokalnych w procesach decyzyjnych”. Do działań priorytetowych dla realizacji wizji rozwoju województwa zaliczono: „Tworzenie warunków do rozwoju usług upowszech- 
niających aktywny styl życia i rozwój społeczeństwa obywatelskiego, [...] aktywizowanie zawodowo i społecznie mieszkańców regionu”, jak również: „Rozwijanie współpracy i partnerstwa wewnątrzregionalnego zarówno podmiotów publicznych, gospodarczych, jak i mieszkańców" (Strategia Rozwoju Województwa... 2013, s. 68).

Wymienione założenia posłużyły do sformułowania najważniejszych obszarów, celów i kierunków działania. W obszarze noszącym nazwę „Szanse rozwojowe mieszkańców” wyznaczono jako jeden z celów operacyjnych: „Harmonia społeczna i wysoki kapitał zaufania oraz dogodne warunki życia mieszkańców”, a w ramach jego realizacji zaplanowano: „Wdrażanie instrumentów wspierających udział mieszkańców w procesach decyzyjnych na szczeblu lokalnym i regionalnym oraz rozwój idei governance" (Strategia Rozwoju Województwa... 2013, s. 92).

W Strategii przyjęto założenie, że poszczególne subregiony województwa śląskiego ${ }^{2}$, z uwagi na duże zróżnicowanie ich potencjałów, wypracują własne strategie i programy rozwoju (Strategia Rozwoju Województwa... 2013, s. 112).

Za przykład posłuży nam Strategia Rozwoju Subregionu Zachodniego na lata 2014-2020 (Strategia Rozwoju Subregionu...), w której do priorytetów strategicznych zaliczono: „Działania obejmujące inwestycje w szeroko rozumiany kapitał ludzki”, które skupiają się m.in. na zwiększaniu świadomości obywatelskiej mieszkańców i poprawie poziomu aktywności gospodarczej i społecznej. Na tej podstawie określono cel strategiczny: „Wysoka jakość kapitału ludzkiego zwiększająca szanse rozwoju indywidualnego oraz wspierająca rozwój społeczny i gospodarczy subregionu”, do którego sformułowano jeden z celów szczegółowych: „Zaangażowanie mieszkańców w rozwój swoich miejscowości i rozwój społeczeństwa obywatelskiego". Osiągnięcie tego celu będzie możliwe m.in. dzięki inicjowaniu projektów umożliwiających mieszkańcom angażowanie się w rozwój swoich miejscowości i rozwój reprezentowanych środowisk, podnoszenie odpowiedzialności mieszkańców za stan przestrzeni publicznych oraz realizację działań podnoszących poziom integracji społeczności lokalnych w subregionie.

Stolicą subregionu zachodniego jest Rybnik. W opracowaniu założeń Strategii Zintegrowanego Rozwoju Miasta Rybnika do roku 2020 (Strategia Zintegrowanego... 2015) partycypacja społeczna uwzględniona została w priorytecie: „Jakość zarządzania miastem”, do którego zaliczono dwa cele: „Szeroki udział mieszkańców w procesach decyzyjnych w mieście” oraz „Wysoka aktywność sektora obywatelskiego umożliwiająca mieszkańcom włączanie się w procesy rozwoju lokalnego". Przykład Strategii Rybnika wskazuje na spójność jej założeń z zapisami regionalnych dokumentów strategicznych, przy jednoczesnej dbałości o uwzględnienie specyfiki uwarunkowań lokalnych. Dotychczasowe rezultaty partycypacji mieszkańców w decydowaniu o obliczu tego miasta dają podstawę, by sądzić, że przyjęte założenia będą należycie wprowadzone w życie (Sobol 2013).

\footnotetext{
2 Województwo śląskie dzieli się na subregiony: północny, centralny, zachodni i południowy.
} 


\section{Dobre praktyki aktywizowania mieszkańców w miastach województwa śląskiego}

Cele i założenia zapisane w dokumentach strategicznych muszą znaleźć odzwierciedlenie w konkretnych działaniach, których powodzenie w dużej mierze zależy od przyjętego sposobu ich realizacji.

Przykładem wykorzystania konsultacji społecznych był proces projektowania uchwały na temat zasad i trybu prowadzenia konsultacji społecznych w Częstochowie (Uchwała nr 715/LXII/2010). Inicjatorzy konsultacji chcieli tą drogą osiągnąć dwa cele: uregulować procedury konsultacyjne i aktywizować mieszkańców miasta do udziału w tej formie partycypacji obywatelskiej. Projekt rozpoczął się szeroko zakrojoną akcją informacyjną. Pierwszy etap służył budowie interaktywnej platformy internetowej, dzięki której mieszkańcy w prosty sposób mogli się zapoznać z harmonogramem i opisem procesu konsultacji czy wymieniać opinie na jego temat. W drugim etapie przeprowadzono serię szkoleń w zakresie prowadzenia konsultacji społecznych dla urzędników, pracowników jednostek i spółek miejskich oraz przedstawicieli rad dzielnic. Trzeci etap stanowiło przeprowadzenie pilotażowych konsultacji społecznych dotyczących przygotowania uchwały regulującej zasady organizacji konsultacji w Częstochowie. W ostatnim etapie pracownicy urzędu miasta odpowiedzialni za proces konsultacyjny opracowali projekt uchwały o trybie i zasadach przeprowadzania konsultacji społecznych. Rada miasta przegłosowała niniejszą uchwałę, nadając tym samym moc prawną projektowi, który powstał przy współudziale mieszkańców. Dodatkowym efektem opisanego projektu było wydzielenie w urzędzie miasta Biura Inicjatyw Lokalnych i Konsultacji Społecznych odpowiedzialnego za stronę organizacyjną konsultacji w Częstochowie. Biuro jest m.in. koordynatorem wprowadzonego od 2015 r. w tym mieście budżetu obywatelskiego.

Pierwszym miastem, które w województwie śląskim wprowadziło budżet partycypacyjny, była Dąbrowa Górnicza. Od początku prac nad Dąbrowskim Budżetem Partycypacyjnym (DBP), który wdrożono w styczniu 2013 r., dokładano starań, by zasługiwał on na miano obywatelskiego. W pracach nad jego przygotowaniem uczestniczyli mieszkańcy, władze i urzędnicy. DBP jest nie tylko dobrze zorganizowanym procesem, ale przede wszystkim elementem kompleksowej polityki współpracy władz samorządowych miasta z mieszkańcami, gdzie partycypacja jest istotnym założeniem (Mapa... 2014, s. 17 i n.). DBP został wysoko oceniony w raporcie „Budżet partycypacyjny. Ewaluacja” (Kębłowski 2014, s. 13-21) i jako jeden z nielicznych w Polsce spełnił wszystkie podstawowe kryteria wynikające z definicji budżetu partycypacyjnego, takie jak:

- bieżąca komunikacja i dialog z mieszkańcami (m.in. spotkania z mieszkańcami, organizacja dzielnicowych forum mieszkańców, strona internetowa DBP);

- jasno określone środki finansowe i zasady finansowania;

- objęcie budżetem obszaru całego miasta;

- wiążący charakter;

- cykliczność. 
Przyjęto zasadę, że DBP ma charakter procesu samouczącego się (Mapa... 2014, s. 36). W związku z tym w kolejnych jego edycjach procedura jest udoskonalana. Metodologia DBP pozwala ustalać mieszkańcom, które ze zgłoszonych propozycji powinny zostać zrealizowane, albo dokonywać ich preselekcji przed przeprowadzeniem wyborów powszechnych.

\section{Zakończenie}

Partycypacja obywatelska ma istotne znaczenie dla kierunków rozwoju miast. Jednocześnie analiza społeczeństwa obywatelskiego oraz mechanizmów uspołecznienia wskazuje na wiele słabości systemu demokratycznego w Polsce. Słabości te dotyczą zarówno polityki władz, jak i postaw obywatelskich samych Polaków. Wzrost możliwości angażowania się przez „Kowalskiego” widoczny jest głównie w przeciągu ostatnich kilku lat. Możliwości te są przedmiotem zarówno regulacji ogólnokrajowych, jak i lokalnie tworzonych rozwiązań.

Realizacja polityki uspołecznienia wymaga z jednej strony działań ze strony władz lokalnych, a z drugiej pozytywnej odpowiedzi mieszkańców na zaproszenie do współpracy. Pomimo przykładów dobrych praktyk w większości polskich miast obserwuje się natomiast kontestowanie zdobyczy idei demokratycznych. Przejawia się to m.in. w niskiej frekwencji w wyborach powszechnych, w tym na poziomie lokalnym, małej liczbie referendów oraz innych rozwiązań angażowania mieszkańców, jak np. inicjatywa obywatelska czy budżety partycypacyjne. Sytuacja taka wynika ze złożonych uwarunkowań, w tym z braku doświadczeń obywatelskich oraz braku dobrej atmosfery wokół udziału mieszkańców w sprawach publicznych. Zauważyć jednocześnie należy, iż skala wpływu mieszkańców na rozwój lokalny w dużym stopniu zależy od woli i stymulowania różnych postaw społecznych przez przedstawicieli władzy. Ich zaangażowanie przekłada się na rozwiązania formalne i na praktykę. Autorytet władzy oraz nadanie uspołecznieniu wysokiej rangi w polityce lokalnej stanowią szczególnie istotne bodźce do „wskrzeszenia” potencjału obywatelskiego.

Dobre praktyki partycypacji obywatelskiej zaobserwowane w polityce rozwoju miast województwa śląskiego, choć przedstawione w bardzo syntetycznej formie, pokazują, że włączanie mieszkańców w sprawy miasta jest nie tylko możliwe, ale także przynosi wymierne korzyści dla całej wspólnoty.

\section{Bibliografia}

Arnstein S.R., 1969, A ladder of citizen participation, "Journal of the American Institute of Planners" vol. 35, No. 4, 10.1080/01944366908977225 (dostęp 14 lutego 2017).

Biała księga wsparcia partycypacji publicznej w Polsce. Dokument przyjęty w wyniku konsultacji propozycji wypracowanych przez Partnerstwo projektu „Decydujmy razem”, 2014, Instytut Spraw Publicznych, Warszawa, http://www.decydujmyrazem.pl/files/Biala_Ksiega[2].pdf, (dostęp 15 stycznia 2017). 
Borek A., Fenrych P., Margol K., 2010, Raport z monitoringu realizacji zasady partycypacji społecznej w samorzadach lokalnych, Fundacja Rozwoju Demokracji Lokalnej, Warszawa.

Castells M., 1983, The city and the grassroots, University of California Press, Berkeley.

Diagnoza społeczna 2015, 2015, red. J. Czapiński, T. Panek, Rada Monitoringu Społecznego, Warszawa, http://www.diagnoza.com/ (dostęp 20 stycznia 2017).

Foster-Fishman P.G., Pierce S.J., Van Egeren L.A., 2009, Who participates and why: Building a process model of citizen participation, "Journal of Health Education and Behaviour" vol. 36, No. 3, 550-569, DOI: 10.1177/1090198108317408 (dostęp 14 lutego 2017).

Fukuyama F., 1997, Zaufanie. Kapitał społeczny a droga do dobrobytu, przeł. A. Śliwa, L. Śliwa, Wydawnictwo Naukowe PWN, Warszawa-Wrocław.

Hausner J., Izdebski H., Lachiewicz W., Mączyński M., Mazur S., Nelicki A., Nowotarski B., Surówka K., Szymczak R., Zachariasz I., Zawicki M., 2014, Narastajace dysfunkcje, zasadnicze dylematy, konieczne dziatania: raport o stanie samorzadności terytorialnej w Polsce, Uniwersytet Ekonomiczny w Krakowie, Małopolska Szkoła Administracji Publicznej, Kraków.

Kębłowski W., 2014, Budżet partycypacyjny. Ewaluacja, Instytut Obywatelski, Warszawa.

Kondycja sektora organizacji pozarządowych w Polsce 2015. Raport z badań, 2016, Stowarzyszenie Klon/ Jawor, Warszawa, http://www.klon.org.pl/ (dostęp 20 stycznia 2017).

Kooiman J., Van Vliet M., 1993, Governance and public management, [w:] Managing public organisations, eds. K. Eliassen, J. Kooiman, Sage, London.

Krakowiak-Drzewiecka M., 2015, Skutki i perspektywy przeobrażeń komunikacji w środowisku lokalnym, [w:] Wspólnoty lokalne jako uczestnik i podmiot procesów transformacji gospodarczej, red. E. Zeman-Miszewska, A. Jakubowska, M. Krakowiak-Drzewiecka, Wydawnictwo Uniwersytetu Ekonomicznego w Katowicach, Katowice.

Mapa wspierania aktywności obywatelskiej w Dąbrowie Górniczej, 2014, Ogólnopolska Federacja Organizacji Pozarządowych i Ośrodek Badania Aktywności Lokalnej, Warszawa, http://www.instytutobywatelski.pl/ wp-content/uploads/2014/07/budzet-partycypacyjny-web.pdf (dostęp 20 stycznia 2017).

Michels A., De Graff L., 2010, Examining citizen participation: Local participatory policy making and democracy, "Local Government Studies" vol. 36., iss. 4.

Olech A., 2013, Kiedy mieszkańcy uczestnicza w podejmowaniu decyzji, [w:] Przepis na uczestnictwo. Diagnoza partycypacji publicznej w Polsce, t. 2, red. A. Olech, Instytut Spraw Publicznych, Warszawa.

Projekt ustawy o współdziałaniu w samorządzie terytorialnym na rzecz rozwoju lokalnego i regionalnego oraz o zmianie niektórych ustaw, Sejm Rzeczypospolitej Polskiej, druk nr 1699, 30 sierpnia 2013, Warszawa, http://orka.sejm.gov.pl/Druki7ka.nsf/0/FAD897F9D8FE723AC1257BE300319B45/\%24File/1699. pdf (dostęp 15 stycznia 2017).

Putnam R., 1995, Demokracja w działaniu, przeł. J. Szacki, Znak, Warszawa.

Sobol A., 2013, Rola społeczności lokalnej w realizacji zrównoważonego rozwoju - przykład miasta Rybnika, [w:] Tendencje w ekonomii i finansach. Konteksty teoretyczne i rozwiazania praktyczne, red. H. Buk, C. Olszak, M. Rówińska, E. Ziemba, Uniwersytet Ekonomiczny w Katowicach, Katowice.

Sobol A., 2014, Crowdfunding jako oddolne narzędzie realizacji zrównoważonego rozwoju, [w:] Gospodarka regionalna i międzynarodowa, red. B. Kryk, Uniwersytet Szczeciński, Szczecin. Zeszyty Naukowe nr 826, t. 2.

Strategia Rozwoju Subregionu Zachodniego na lata 2014-2020, http://www.subregion.pl/strategia_subregionu_zachodniego_ver2.0.pdf (dostęp 20 stycznia 2017).

Strategia Rozwoju Województwa Śląskiego „Śląskie 2020+”, 2013, Urząd Marszałkowski, Katowice, http:// slaskie.pl/ (dostęp 20 stycznia 2017).

Strategia Zintegrowanego Rozwoju Miasta Rybnika do roku 2020, 2015, Urząd Miasta, Rybnik, http://rybnik. pl/ (dostęp 20 stycznia 2017).

Swianiewicz P., 2012, Partycypacja społeczna $w$ realizacji polityk miejskich, [w:] Partycypacja obywateli i podmiotów obywatelskich w podejmowaniu rozstrzygnięć publicznych na poziomie lokalnym, red. M. Stec, M. Mączyński, Wolters Kluwer Business, Warszawa.

Uchwała nr 715/LXII/2010 Rady Miasta Częstochowy z dnia 28 czerwca 2010 r. w sprawie zasad i trybu przeprowadzania konsultacji społecznych z mieszkańcami Częstochowy, http://konsultacje.czestochowa. pl/?page_id=252 (dostęp 12 lutego 2017). 
Ustawa z dnia 20 czerwca 2002 r. o bezpośrednim wyborze wójta, burmistrza i prezydenta miasta (Dz.U. z 2002 r. Nr 113, poz. 984 z późn. zm.).

Ustawa z dnia 24 kwietnia 2003 r. o działalności pożytku publicznego i o wolontariacie (Dz.U. z 2003 r. Nr 96 , poz. 873 z późn. zm.).

Ustawa z dnia 8 marca 1990 r. o samorządzie gminnym (Dz.U. z 1990 r. Nr 16, poz. 95 z późn. zm.).

Wouters M., Hardie-Boys N., Wilson C., 2011, Evaluating public input in National Park Management Plan reviews: Facilitators and barriers to meaningful participation in statutory processes, "Science for Conservation" 308, http://www.doc.govt.nz/documents/science-and-technical/sfc308.pdf (dostęp 14 lutego 2017). 